\title{
THE EFFECT OF RALEUKIN ON THE VALUES OF GLUCOSE HOMEOSTASIS OF NORMOGLYCEMIC RATS IN GLUCOSE LOAD
}

\author{
I.P.Bukhtiyarova, S.M.Drogovoz*, O.M.Ischenko**, E.L.Toryanik*
}

Donetsk National Medical University named after M.Gorky

National University of Pharmacy*

Research Institute of High-Purity Biopharmaceuticals**

Key words: Intraperitoneal and oral glucose tolerance test; hypoglycemic effect; raleukin

\begin{abstract}
Diabetes mellitus (DM) remains the only noncontagious disease for today, which prevalence, according to the World Health Organization, has reached epidemic proportions. According to the results of recent research proinflammatory cytokines, namely interleukin-1 (IL-1), play an important role in the pathogenesis of both types of diabetes. Therefore, drugs that can inhibit the activity of IL-1 by suppressing its receptors, improve survival and normalize the functional activity of $\beta$-cells of the pancreas are promising anti-diabetic agents. The article presents the results of the pharmacological screening of hypoglycemic properties of receptor antagonist IL-1 raleukin obtained in the Research Institute of High-Purity Biopharmaceuticals (St. Petersburg) in normoglycemic rats under conditions of tolerance tests to carbohydrates. It has been found that in the intraperitoneal glucose tolerance test the antagonist of IL-1 raleukin shows a significant hypoglycemic effect in the doses of 7 and $10 \mathrm{mg} / \mathrm{kg}$, i.e. it is a promising antidiabetic agent. In the oral glucose tolerance test raleukin in the dose of $7 \mathrm{mg} / \mathrm{kg}$ revealed the same hypoglycemic activity. This dose is a conditionally effective dose of the drug by the hypoglycemic effect; it can be used in further studies of anti-diabetic properties of raleukin. The results experimentally substantiate the high efficiency and expediency of IL-1 receptors blockade as one of the ways of correcting hyperglycemia in type 1 diabetes.
\end{abstract}

$\mathrm{D}$ iabetes mellitus (DM) remains the only noncontagious disease for today, which prevalence, according to the World Health Organization, has reached epidemic proportions [3]. According to the data of the International Diabetes Federation in 2011 the number of patients suffering diabetes in the world was 366 million. And as scientists predict, in 2030 they will be more than 500 million [2, 6]. In 2011 diabetes caused 4.6 million of deaths. Over the past 10 years the number of diabetic patients in Ukraine has increased by more than 1.5 times. There are more than 1 million patients with diabetes; it is about $2 \%$ of the total population [6]. The actual prevalence of diabetes is 3-4 times greater than recorded, indicating a pandemic of diabetes among adults. Therefore, optimization of treatment of diabetes is one of the pressing health and social problems.

Quite a great content knowledge in the field of diabetes pathophysiology and the presence of a wide range of therapeutic opportunities for its treatment have failed to improve the metabolic control of the disease at the stage of glucose tolerance to the fullscaled clinical picture of diabetes. A great number of international and domestic research is devoted to development of new methods to treat diabetes taking into account its pathogenic mechanisms $[1,17]$. One of the perspective directions of optimization of immunosuppressive therapy is anticytokine diabetes therapy [15].

According to the results of recent research proinflammatory cytokines, namely interleukin-1 (IL-1), play an important role in the pathogenesis of both types of dia-

\footnotetext{
I.P.Bukhtiyarova - Candidate of Pharmacy, associate professor of the Department of Management and Economy of Pharmacy of the Donetsk National Medical University named after M.Gorky
}

S.M.Drogovoz - Doctor of Medicine, professor of the Pharmacology Department of the National University of Pharmacy (Kharkiv)

O.M.Ischenko - Candidate of Biology, head of the laboratory of the Research Institute of High-Purity Biopharmaceuticals (St. Petersburg) betes $[14,16]$. Therefore, drugs that can inhibit the activity of IL-1 by suppressing its receptors, improve survival and normalize the functional activity of $\beta$-cells of the pancreas are promising anti-diabetic agents $[10,11,12,13]$. The list of anti-diabetic drugs, which are in the formulary system of Ukraine, contains no drugs with such mechanism of action.

The aim of this study was to conduct the pharmacological screening of hypoglycemic properties of receptor antagonist IL-1 raleukin obtained in the Research Institute of High-Purity Biopharmaceuticals (St. Petersburg) in normoglycemic rats under conditions of tests of tolerance to carbohydrates.

\section{Materials and Methods}

Screening studies of the hypoglycemic activity of raleukin were conducted within a wide range of doses in intact rats. The intraperitoneal glucose tolerance test (IPGTT) was reproduced by intraperitoneal administration of $2 \mathrm{~g}$ of glucose per $\mathrm{kg}$ of the body weight to rats males. The oral glucose tolerance test (OGTT) was reproduced by intragastric administration 


\section{The hypoglycemic effect of raleukin in animals with the normal glucose homeostasis in the intraperitoneal glucose tolerance test $(M \pm m, n=6)$}

\begin{tabular}{|c|c|c|c|c|c|}
\hline \multirow{2}{*}{ Group of animals } & \multirow{2}{*}{$\begin{array}{c}\text { Basal glycemia, } \\
\mathrm{mmol} / \mathrm{l}\end{array}$} & \multicolumn{3}{|c|}{ The level of blood glucose $(\mathrm{mmol} / \mathrm{l})$ in } & \multirow{2}{*}{$\begin{array}{c}\mathrm{AGC} \\
\mathrm{mmol} / / \cdot \min \end{array}$} \\
\hline & & 1 hour & 2 hour & 3 hour & \\
\hline Control & $8.09 \pm 0.61$ & $7.95 \pm 0.94$ & $6.64 \pm 0.49$ & $5.32 \pm 0.34^{*}$ & $761.4 \pm 23.1$ \\
\hline Raleukin, $3 \mathrm{mg} / \mathrm{kg}$ & $7.86 \pm 0.54$ & $7.21 \pm 0.67$ & $5.23 \pm 0.56 * \&$ & $4.56 \pm 0.43 * \&$ & $722.7 \pm 47.3$ \\
\hline Raleukin, $7 \mathrm{mg} / \mathrm{kg}$ & $7.11 \pm 0.42$ & $5.17 \pm 0.45 * / * * \#$ & $3.78 \pm 0.33^{* * \#}$ & $3.36 \pm 0.17 * \#$ & $601.2 \pm 52.6^{* *}$ \\
\hline Raleukin, $10 \mathrm{mg} / \mathrm{kg}$ & $7.74 \pm 0.55$ & $6.68 \pm 0.58$ & $4.92 \pm 0.28 * * * \&$ & $3.71 \pm 0.23^{* *}$ & $645.3 \pm 39.8^{* *}$ \\
\hline Metformin, $30 \mathrm{mg} / \mathrm{kg}$ & $8.16 \pm 0.78$ & $7.03 \pm 0.51$ & $5.19 \pm 0.35 * / * * \&$ & $4.27 \pm 0.32 * \&$ & $661.5 \pm 34.7^{* *}$ \\
\hline
\end{tabular}

Note. Statistically significant differences $(p \leq 0.05):{ }^{*}$ - to the basal glycemia; ${ }^{* *}$ - to the control group, \# - to metformin, $\&$ - to raleukin, $7 \mathrm{mg} / \mathrm{kg} ; \mathrm{n}$ - the number of animals in the group

of glucose in the dose of $3 \mathrm{~g} / \mathrm{kg}$ of the body weight [4].

Raleukin was injected subcutaneously once before reproduction of each test in the doses of 3,7 and $10 \mathrm{mg} / \mathrm{kg}$, the reference drug metformin as a single intragastrical dose of $30 \mathrm{mg} / \mathrm{kg}[7,9]$. Doses of raleukin for screening studies were selected according to the results of the previous studies [8].

Blood samples for glucose analysis were taken before and in 1 , 2 and 3 hours after administration of the drugs under research in the IPGTT and in $0.5,1$, and 2 hours in the OGTT. The glycemic response during the carbohydrate tolerance tests was evaluated by the integrated glucose and the area under the glycemic curve (AGC) [4].

Blood glucose was evaluated by the glucose oxidase test using the glucose enzymatic analyzer "Eksan-D" (Lithuania); AGC was calculated by "Mathlab" computer program [4].

When recording the results as mean \pm standard error the statistical reliability of intergroup differences was calculated by the Student t-test.

\section{Results and Discussion}

The results are shown in Tables 1-2.

Basal glycemia after the IPGTT in all groups of experimental animals was in the range of 7.11$8.16 \mathrm{mg} / \mathrm{kg}$ (Table 1 ).

One hour after administration of only raleukin in the dose of
$7 \mathrm{mg} / \mathrm{kg}$ showed a reliable hypoglycemic effect by 1.4 times reduction of the level of glucose in the blood serum of animals compared to basal glycemia. Raleukin in other doses and the reference drug metformin showed a tendency to the hypoglycemic action (1.1 times raleukin in the dose of $3 \mathrm{mg} / \mathrm{kg}$, 1.2 times - raleukin in the dose of $10 \mathrm{mg} / \mathrm{kg}, 1.2$ times - metformin).

Two hours after administration of raleukin in the dose of $3 \mathrm{mg} / \mathrm{kg}$ the blood glucose level in rats significantly decreased 1.5 times compared to basal glycemia, but it was not significantly different from the control group value. Under the effect of raleukin in the dose of $7 \mathrm{mg} / \mathrm{kg}$ the content of glucose 1.9 times decreased in two hours, and it was significantly different from both basal glycemia, and the control group value. Under the influence of raleukin in the dose of $10 \mathrm{mg} / \mathrm{kg}$ and the reference drug metformin the content of glucose 1.6 times decreased. Thus, in two hours of the research raleukin in the dose of $7 \mathrm{mg} / \mathrm{kg}$ showed the most expressed hypoglycemic effect.

A similar decrease in glucose was observed in three hours of the study. In the control group of rats the glucose content in the blood spontaneously decreased by 1.5 times in relation to the maximum level of glycemia $(8.09 \pm 0.61)$. It was also significantly different from basal glycemia. Under the effect of raleukin in the doses of 3,7 , $10 \mathrm{mg} / \mathrm{kg}$ the carbohydrate level decreased by 1.7, 2.1 and 2.1 times, respectively. In the group of animals that received raleukin in the doses of 7 and $10 \mathrm{mg} / \mathrm{kg}$ of the blood glucose levels were not significantly different from basal glycemia. Under the influence of raleukin in the dose of $3 \mathrm{mg} / \mathrm{kg}$ decrease of the blood glucose level was not significantly different from the value in the control group of rats.

In three hours of the study metformin also showed the hypoglycemic effect, 1.9 times decreased the blood glucose level in rats; in three hours the glycemia level in this group of animals was not significantly different from that observed in the control group.

The hypoglycemic effect of raleukin in the doses of 7 and $10 \mathrm{mg} / \mathrm{kg}$, as well as metformin confirmed by the values of AGC $-601.2 \pm 52.6$ and $645.3 \pm 39.8 \mathrm{mg} / \mathrm{l} \bullet \mathrm{min}, 661.5 \pm$ $\pm 34.7 \mathrm{mg} / \mathrm{l} \bullet \mathrm{min}$, respectively, which were significantly different from those observed in the control group (Table 1).

In the OGTT basal glycemia was observed within $4.97 \pm 0.25$ $5.88 \pm 0.37 \mathrm{mmol} / \mathrm{l}$ (Table 2). In 30 minutes after administration of the drugs under research only raleukin in the dose of $7 \mathrm{mg} / \mathrm{kg}$ revealed a reliable hypoglycemic activity; the glucose content in the blood was 1.2 times lower than basal glycemia and 1.4 times lower than in the control group. Other 
The hypoglycemic effect of raleukin in animals with normal glucose homeostasis in the oral glucose tolerance test $(M \pm m, n=6)$

\begin{tabular}{|l|c|c|c|c|c|}
\hline \multirow{2}{*}{ Group of animals } & \multirow{2}{*}{$\begin{array}{c}\text { Basal glycemia, } \\
\mathrm{mmol} / \mathrm{l}\end{array}$} & \multicolumn{2}{|c|}{ The level of blood glucose $(\mathrm{mmol} / \mathrm{l})$ in } & \multirow{2}{*}{$\begin{array}{c}\text { AGC } \\
\end{array}$} \\
\cline { 3 - 5 } & & 0.5 hour & 1 hour & 2 hour & mmol/l $\cdot \min$ \\
\hline Control & $5.76 \pm 0.32$ & $5.81 \pm 0.43$ & $5.15 \pm 0.51$ & $4.74 \pm 0.34^{*}$ & $630.0 \pm 44.2$ \\
\hline Raleukin, $3 \mathrm{mg} / \mathrm{kg}$ & $5.24 \pm 0.28$ & $5.12 \pm 0.36$ & $4.46 \pm 0.32$ & $4.02 \pm 0.41^{*}$ & $555.6 \pm 53.1$ \\
\hline Raleukin, $7 \mathrm{mg} / \mathrm{kg}$ & $4.97 \pm 0.25$ & $4.16 \pm 0.18^{*} / /^{* *}$ & $3.81 \pm 0.29^{*} / /^{* *}$ & $3.27 \pm 0.19^{*} / *^{* *} \#$ & $494.4 \pm 31.8^{* *}$ \\
\hline Raleukin, $10 \mathrm{mg} / \mathrm{kg}$ & $5.41 \pm 0.49$ & $4.87 \pm 0.32$ & $4.09 \pm 0.59^{*}$ & $3.56 \pm 0.22^{* *} /{ }^{* *}$ & $538.2 \pm 39.5$ \\
\hline Metformin, $30 \mathrm{mg} / \mathrm{kg}$ & $5.88 \pm 0.37$ & $4.79 \pm 0.51$ & $4.12 \pm 0.24^{*}$ & $3.83 \pm 0.15^{*} / * *$ & $582.6 \pm 27.9$ \\
\hline
\end{tabular}

Note. Statistically significant differences ( $\leq \leq 0.05)$ : * to the basal glycemia; ${ }^{* *}$ - to the control group, \# - to metformin, $\&$ - to raleukin, $7 \mathrm{mg} / \mathrm{kg} ; \mathrm{n}$ - the number of animals in the group.

drugs revealed a tendency to the hypoglycemic action.

In the OGTT in an hour after administration of these drugs the most expressed hypoglycemic effect was also observed in case of raleukin in the dose of $7 \mathrm{mg} / \mathrm{kg}$ (the blood glucose level was significantly 1.2 times lower than the level of basal glycemia). Raleukin in the dose of $10 \mathrm{mg} / \mathrm{kg}$ and the reference drug metformin showed a reliable normoglycemic effect in relation to basal glycemia (the blood glucose was decreased by 1.3 and 1.4 times, respectively), but their of the hypoglycemic action did not differ significantly from the similar value in the control group. Raleukin in the dose of $3 \mathrm{mg} / \mathrm{kg}$ in an hour of the study showed a tendency to the hypoglycemic activity.

In two hours after the application all of the drugs studied revealed a reliable hypoglycemic effect in relation to basal glycemia and 1.3 times in relation to the value of the control group. Raleukin in the dose of $10 \mathrm{mg} / \mathrm{kg}$ and metformin showed almost the same reliable hypoglycemic effect in relation to the control group (on the average 1.3 times) and in relation to basal glycemia (on the average 1.5 times). Raleukin in the dose of $3 \mathrm{mg} / \mathrm{kg}$ significantly reduced the blood glucose of experimental animals by 1.3 times, but this value was not significantly different from the value of the control group. By the effect on AGC only raleukin in the dose of $7 \mathrm{mg} / \mathrm{kg}$ showed a reliable normalized effect on the control group (reduced by 1.3 times).

Thus, according to the research carried out raleukin in the dose of $7 \mathrm{mg} / \mathrm{kg}$ has demonstrated the most expressed hypoglycemic effect under conditions of the glucose load.

It is known that IL-1 inhibits the glucose stimulated insulin secretion and violates the normal structure of islets of Langerhans; it results in decreased survival of $\beta$-cells and induces their apoptosis $[5,9$, $10]$. The abovementioned is connected with the fact that $\beta$-cells themselves have the highest density of IL-1 receptors. The ability of raleukin to block IL-1 receptors inhibits apoptosis in $\beta$-cells and has the protective effect on them (protects against violations). This makes it a promising antidiabetic drug that can affect the diabetes pathogenetic link, which modern antidiabetic agents can not have effect on.

\section{CONCLUSIONS}

It has been found that in the intraperitoneal glucose tolerance test the antagonist of IL-1 raleukin shows a significant hypoglycemic effect in the doses of 7 and $10 \mathrm{mg} / \mathrm{kg}$, i.e. it is a promising antidiabetic agent. In 3 hours after its introduction raleukin in the dose of $7 \mathrm{mg} / \mathrm{kg}$ revealed the maximum hypoglycemic activity that exceeded 1.2 times the effect of the reference drug metformin by its degree of intensity. In the oral glucose tolerance test raleukin in the dose of $7 \mathrm{mg} / \mathrm{kg}$ also showed the highest hypoglycemic activity. This dose is a conditionally effective dose of the drug by the hypoglycemic effect; it can be used in further studies of anti-diabetic properties of raleukin.

\section{REFERENCES}

1. Балаболкин М.И., Клебанова Е.М., Креминская В.М. Лечение сахарного диабета и его осложнений. M., 2005. - 512 c.

2. Дедов И.И. // Вестник Росс. академии мед. наук. - 2012. - №1. - С. 7-13.

3. Дедов И.И., Шестакова М.В. Сахарный диабет: Руководство для врачей. - М., 2003. - С. 151-175.

4. Доклінічні дослідження лікарських засобів: Метод. рекоменд. / За ред. чл.-кор. НАМН України О.В.Стефанова. - К.: Авіценна, 2001. - 528 с. 
5. Симбирцев А.С. Медицинские препараты на основе белков семейства интерлейкина-1 / В кн.: Справочник по иммунотерапии для практического врача. - С.Пб.: Изд-во «Диалог», 2002. C. 152-165.

6. Сунцов Ю.И., Болотская Л.Л., Маслова О.В. и др. // Сахарный диабет. - 2011. - №1. - С. 15-18.

7. Шумейко О.Г. Експериментальне обгрунтування застосування екстракту з мідії чорноморської (Mytilus galloprovincialis Lam.) у комплексній терапії иукрового діабету: Дис. ... канд. мед. наук: 14.01.14 - ендокринологія. - Х., 2009. - 153 с.

8. Щокіна К.Г. Органотропні ефекти рекомбінантного антагоніста рещепторів інтерлейкіну-1 (експериментальне дослідження): Дис. ... докт. фарм. наук: 14.03.05 - фармакологія. - Х., 2011. $440 \mathrm{c}$.

9. Alexandraki K., Piperi C., Kalofoutis C. et al. // Ann. N. Y. Acad. Sci. - 2006. - Vol. 1084. - P. 89-117.

10. Andersson A.K., Borjesson A., Sandgren J. et al. // Mol. Cell Endocrinol. - 2005. - Vol. 240. - P. 50-57.

11. Börjesson A., Carlsson C. // J. Endocrinol. - 2007. - Vol. 192 (2). - P. 381-387.

12. Fève B., Bastard J.-P. // Nature Rev. Endocrinol. - 2009. - №5. - P. 305-311.

13. Lagathu C., Yvan-Charvet L., Bastard J.P. et al. // Diabetol. - 2006. - №49. - P. 2162-2173.

14. Larsen C.M., Faulenbach M., Vaag A. et al. // N. Engl. J. Med. - 2007. - Vol. 356. - P. 1517-1526.

15. Larsen C.M., Faulenbach M., Vaag A. et al. // Diabetes Care. - 2009. - Vol. 32. - P. 1663-1668.

16. Mandrup-Poulsen T., Bendtzen K., Dinarello C.A. et al. //J. Immunol. - 1987. - Vol. 139 (12). - P. 4077-4082.

17. World Health Organization. Use of glycated haemoglobin (HbA1c) in the diagnosis of diabetes mellitus. Abbreviated report of a WHO consultation. - World Health Organization, 2011 (WHO/NMH/CHP) CPM/11.1).

\section{ВПЛИВ РАЛЕЙКІНУ НА ПОКАЗНИКИ ГЛЮКОЗНОГО ГОМЕОСТАЗУ НОРМОГЛІКЕМІЧНИХ ЩУРІВ ПРИ ГЛЮКОЗНОМУ НАВАНТАЖЕННI}

І.П.Бухтіярова, С.М.Дроговоз*, О.М.Іщенко**, Е.Л.Торяник*

Донецький національний медичний університет ім. М.Горького, Національний фармацевтичний університет*, Науково-дослідний інститут особливо чистих біопрепаратів **

Ключові слова: внутрішньоочеревинний та пероральний тест толерантності до глюкози; гіпоглікемічна дія; ралейкін

Цукровий діабет (ЦД) на сьогодні залишається єдиним неінфекційним захворюванням, поширеність якого, за даними Всесвітньої Організації Охорони Здоров'я, носить характер епідемії. За даними сучасних досліджень важливу роль у патогенезі ЦД обох типів відіграють прозапальні цитокіни, а саме, інтерлейкін-1 (ІЛ-1). Тому препарати, здатні гальмувати активність ІЛ-1 за рахунок пригнічення рецепторів IЛ-1, підвищувати виживаність та нормалізувати функціональну активність $\beta$-клітин підшлункової залози, $\epsilon$ перспективними антидіабетичними засобами. У статті наведені результати фармакологічного скринінгу гіпоглікемічних властивостей антагоніста рецепторів ІЛ-1 ралейкіну, отриманого у Санкт-Петербурзькому НДІ ОЧБП, у нормоглікемічних щурів в умовах тестів толерантності до вуглеводів. Визначено, що у внутрішньоочеревинному тесті толерантності до глюкози антагоніст рецепторів ІЛ-1 ралейкін в дозах 7 та 10 мг/кг виявив достовірну гіпоглікемічну дію, тобто він є перспективним антидіабетичним засобом. У пероральному тесті толерантності до глюкози теж найбільшу гіпоглікемічну активність виявив ралейкін у дозі 7 мг/кг. Ця доза є умовно-ефективною дозою препарату за гіпоглікемічною дією та може бути використана у подальших дослідженнях антидіабетичних властивостей ралейкіну. Результати експериментально обгрунтовують високу ефективність і доцільність блокади рецепторів інтерлейкіну-1 як одного із шляхів корекції гіперглікемії при ЦД 1 типу.

\section{ВЛИЯНИЕ РАЛЕЙКИНА НА ПОКАЗАТЕЛИ ГЛЮКОЗНОГО ГОМЕОСТАЗА НОРМОГЛИКЕМИЧЕСКИХ КРЫС ПРИ ГЛЮКОЗНОЙ НАГРУЗКЕ}

И.П.Бухтиярова, С.М.Дроговоз*, А.М.Ищенко**, Э.Л.Торяник*

Донецкий национальный медицинский университет им. М.Горького, Национальный фармацевтический университет*, Научно-исследовательский институт особо чистых биопрепаратов**

Ключевые слова: внутрибрюшинный и пероральный тест толерантности к глюкозе; гипогликемическое действие; ралейкин

Сахарный диабет (СД) на сегодня остается единственным неинфекционным заболеванием, распространенность которого, по данным Всемирной Организации Здравоохранения, носит характер эпидемии. По результатам современных исследований важную роль в патогенезе СД обоих типов играют провоспалительные цитокины, а именно, интерлейкин-1 (ИЛ-1). Поэтому препараты, способные тормозить активность ИЛ-1 за счет угнетения его рещепторов, повышать выживаемость и нормализовать функциональную активность $\beta$-клеток поджелу- 
дочной железы, являются перспективными антидиабетическими средствами. В статье приведены результаты фармакологического скрининга гипогликемических свойств антагониста рецепторов ИЛ-1 ралейкина, полученного в Санкт-Петербургском НИИ ОЧБП, у нормогликемических крыс в условиях тестов толерантности к углеводам. Определено, что во внутрибрюшинном тесте толерантности к глюкозе антагонист рецепторов Ил-1 ралейкин в дозах 7 и 10 мг/кг обнаружил достоверное гипогликемическое действие, т.е. он является перспективным противодиабетическим средством. В пероральном тесте толерантности к глюкозе такую же гипогликемическую активность проявил ралейкин в дозе 7 мг/кг. Эта доза является условно-эффективной дозой препарата по гипогликемическому действию и может быть использована в дальнейших исследованиях антидиабетических свойств ралейкина. Результаты экспериментально обосновывают высокую эффективность и целесообразность блокады рецепторов ИЛ-1 как одного из путей коррекции гипергликемии при СД 1 типа.

Address for correspondence:

Received in 03.10.2013

12, Melnykova str., Kharkiv, 61002, Ukraine.

Tel. (57) 760-30-69. E-mail: acya@ukr.net.

National University of Pharmacy 